Alena Vališová

Ostravská Univerzita

PETR SVOBOdA

Česke Vysoké Učení Technické v Praze

\title{
HIGHER-EDUCATION TEACHER IN THE CONTEXT OF HIS PROFESSIONAL COMPETENCY
}

\begin{abstract}
Aвstract. Vališová Alena, Svoboda Petr, Higher-Education Teacher in the Context of His Professional Competency [Nauczyciel szkoły wyższej i jego kompetencja zawodowa]. Studia Edukacyjne nr 50, 2018, Poznań 2018, pp. 241-255. Adam Mickiewicz University Press. ISSN 1233-6688. DOI: 10.14746/ se.2018.50.16
\end{abstract}

The study includes an overview of key individual teacher's competencies, their classification and characteristics. The division of competencies is complicated as the individual competencies are interrelated. The substance of the study is a brief definition of the professional competencies of higher-education teachers. The emphasis is placed on the up-to-date teacher's competencies, about which gives an account a number of definitions of this term in both the contemporary pedagogical and psychological literature. The study also deals with the concept of a professional standard and with digital competencies, the importance of which results from the continual development of the existing scientific disciplines (which already traditionally cooperate with the pedagogy) but also from the development of the newly emerging branches. The digital technologies are nowadays more and more necessary thing both for the normal everyday life and for the occupational one as well. The ability to work with a computer itself is just a marginal matter in today's conception of the digital competencies. The technologies are constantly developed and the demands on digital competencies are rising. Digital technologies have developed rapidly in the last few years, which has influenced also the sphere of education. New technologies are becoming an important part of education. The reflection of new teaching trends takes place at the intersection of pedagogical, psychological and sociological disciplines. The development is accelerating rapidly due to the ongoing technological changes and innovations. The study is a part of the TAČR (Technological Agency of the Czech Republic) grant project - "Development of Digital Competencies of Social science Teachers at Secondary Technical Schools", 02/2018-02/2021 PID:TL01000192.

Key words: teacher's competency, profession, higher-education teacher, student, professional standard, personality, professional ethics, digital technology 


\section{Introduction}

The present state of the society and tendencies of its development are sometimes denoted as education society, knowledge society, and learning society. Deep changes and transformation of the contemporary society cannot remain without influence on education, on its general character and also on its individual components and in particular on participants of the educational process. The Europe and the world head more and more towards a knowledge society in which is for the society and economy necessary and important a higher-education system. Graduates of higher-education schools are taking up key positions in the learning society and the needs of these workers are associated with advanced specialized knowledge and skills. Such positions anticipate also a high flexibility and adaptability. The knowledge society needs new quality workers, flexible professionals. Higher-education schools as institutions play an important role in helping the graduates to build their competencies that are associated with the knowledge society, give rise to professions with wide-ranging competencies not only professional but also in a broad social and communication view. The development of these competencies also considerably influences the life's career.

\section{Transformation determinants of higher-education teacher's profession}

Teachers' international document "Adoption of a recommendation concerning the status higher-education teaching personnel", adopted by the General conference of UNESCO in 1997 in Paris, defines the higher-education teachers status. It contains principles and conditions of the academic profession practice and recommends to all member countries to respect it. It deals with the rights, duties and responsibilities of institutions, with rights, duties, responsibilities and liberties of higher-education teachers, preparation for the academic profession and working conditions. The document defines also the higher-education teaching personnel securing the teaching process. This concept includes all persons acting in the institutions or higher-education programmes engaged in the teaching process and the related technical activities, in science and research or provide education services outside the institution by means of audiovisual and computer systems and library services or provide consultancy services. Higher-education teacher is an academic employee of higher-education schools, who performs both the pedagogical and scientific, research, development, artistic or another creative activity. Higher-education teacher has a defined academic career in which he upgrades his expertise and achieves academic degrees. 
The contemporary transformations of the education paradigm and scientific work at higher-education schools influences the professionalism of academic activities that give rise to new demands on the higher-education teachers. ${ }^{1}$ Up-to-date documents of the educational politics guarantee the higher-education schools status as of the community of scientists but at the same time require a high level of pedagogical competency of higher-education teachers, their responsibility for education and prosperity of a mass of students and maintenance of high education standards corresponding to the level of high-education schools.

As main determinants of the academic profession are at present considered:

- Transformation of the higher education system which produces institutional diversification and arrangement of study programmes into various academic degrees;

- Educational demands of the labour market that influence constitution of new study disciplines and subjects and the possibility to find employment of graduates disposing with key competencies;

- New information and communication technologies which are becoming a source of information and function also as intermediary and supporter of student's learning;

- Introduction of various forms and kinds of organization of higher education studies for example distance education, modularization of the curriculum and credit system evaluation;

- Transformation of the student population associated with diversified age and experience structure of students and their personal transformation;

- Development of progressive conceptions and models of the higher-education teaching process for support of students' optimal learning and creation of key competencies; transformation of scientific-research and developmental works at higher education schools, that is considerably influenced by the grant system for which is typical creation of institutional problem-solving teams, often on an international level;

- Changes of working conditions, for example time-limited employment contracts, bankruptcy proceedings, excess work loads, concurrent contracts at more institutions.

Increased importance of education and lifelong learning is associated with the growth of importance of science and its application in all basic spheres of life, with processes of democratization, increasing role of a human-being,

${ }^{1}$ J. Cejpek, K prrirozené autoritě vysokoškolského učitele [To the natural authority of the higher-education teacher], [in:] Relativizace autority a její dopady na současnou mládež [Relativization of authority and its impact on the present-day youth], Ed. A. Vališová a kol., Praha 2005. 
and process of individualization. It is possible to sum up that the academic profession is characterized by the following characteristics:

- High level of scientific erudition;

- Creation of scientific cognition (i.e. scientific - research and explorational activity, work on projects);

- Expert intermediation of this cognition to the young generation (i.e. pedagogical activity);

- Considerable extent of autonomy associated with the academic freedom,

- Phasing of the professional career (academic career),

- High social prestige.

Higher-education teacher holds the highest position in the hierarchy of the teaching profession, what results from both the highest level of education secured by the teacher and the tradition of universities and its appreciation by the society. The profession of a university teacher at the same time holds a high prestige position in ranking of professions in general. ${ }^{2}$ The substantial character of the academic profession is a considerable extent of its autonomy and independence associated with academic freedom and with autonomy of higher-education institutions. The degree of independence of the practice of profession is rising in connection with advancement in the academic career. It comes through decision making about specialization and methods of the scientific research, about conception of the educational contents and teaching, about requirements placed on students and the way of probing of their study results.

It is also reflected in participation of the higher-education teachers in sel$\mathrm{f}$-administration and management of higher- education institutions as far as they are elected in the academic elections. The required high level of scientific erudition is directly associated with a demanding professional performance and academic career of the higher-education teacher. Its acquirement is encoded into the academic titles (academic degrees). The scientific erudition is a "scholarship" which is understood as a profound knowledge of the discipline and its methodology and constant keeping abreast of the state of knowledge in the discipline.

\section{"Labyrinth" of views on division of teacher's professional competencies}

A number of definitions give an account of the currentness of teacher's competencies in both the pedagogical and psychological literature. The term

${ }^{2}$ M. Slavík a kol., Vysokoškolská pedagogika [Academical pedagogy], Praha 2012. 
competency can be defined on a general level as qualification, preparedness, capability to carry out certain activities, operations, behave in a certain manner, fulfil certain functions and social roles. Teacher's competency, formerly was used the term qualification - it concerns a complex of activity knowledge, experiences, skills, well-handled operations and educational readiness but also stances and convictions which the teacher should master. ${ }^{3}$ In the pedagogical dictionary can be find the definition of the teacher's competencies as a complex of professional knowledge, skills, stances and values, significant for performance of the teaching profession. ${ }^{4}$ In a broader conception it concerns competencies acquired by learning, that are at the same time given by genetic potentialities, in the strict sense it is the result of teacher's education.

Beside the detailed enumeration of partial competencies with its characteristics in the professional pedagogical and psychological literature, there are also mentioned definitions of the following three groups of teacher's competencies: ${ }^{5}$

a) Competency to teaching and education - sometimes denoted as methodical (primarily as communicative, diagnostic, and psycho-pedagogical competency).

b) Personality competency (responsibility of the teacher for pedagogical decisions, acceptance of himself and others as well, creativity, temperament, emotional and volitional qualities, self-confidence and so on).

c) Developing competency (in particular informational, research, adaptive, methodological, creative, self-reflective, self-regulative).

It is necessary to stress the mutual interrelation of competencies, more competencies can be involved in fulfilment of one assignment, it support and complement each other. Substantial is the specialization of its contents.

The following part of the text deals with enumeration of competencies that are often specified in relation to the teacher's profession in varying conditions and rising demands on education. ${ }^{6}$

${ }^{3}$ Z. Kolář a kol., Výkladový slovník z pedagogiky [Monolingual dictionary from pedagogy], Praha 2012, p. 64-65.

${ }^{4}$ J. Prúcha, E. Walterová, J. Mareš, Pedagogický slovník. 2. rozšír. a přeprac [Pedagogical dictionary, 2nd extended and reworked edition], Praha 2009, p. 129.

${ }^{5}$ For example: Z. Kolář a kol., Výkladový slovník, p. 65; V. Švec, Klíčové dovednosti ve vyučování a výcviku [Key skills in teaching process and training], Brno 1998, p. 22-23.

${ }^{6}$ In more detail for example: V. Švec, Kličcové dovednosti; Z. Kolář a kol., Výkladový slovnik; M. Tureckiová, Klíčové kompetence manažerů vzdělávání [Key competencies of education managers], [in:] Pokroky v hodnocení klíčových kompetencí [Progress in evaluation of key competencies], Eds. J. Malach, I. Červenková, M. Chmura, Ostrava 2016; M. Šafránková, R. Franěk, Některé aktuální problémy vzdělání, vzdělávání a výchovy v současné společnosti a v českém vysokém učení technickém v Praze [Some current problems of education in the contemporary society and in the Czech technical college in Prague], [in:] Výchova, vzdělávání a výzvy nové doby [Education and challenges 
- Communication competency - places emphasis on the dialog not only between the teacher and student but also among the students themselves, communicative teaching is at the same time empathetic teaching, enables the teacher get to know the students, their views, interests and also problems; to this competency belongs also mutual communication of teachers among themselves and their self-reflection; applies effective manners of communication and cooperation with parents and with other social partners.

- Assertive competency - in practice the teacher often gets into situations in which it is necessary "to assert" his education goals, views, intentions; the teacher can "convince" the school management about his non-traditional methods and forms of work by taking advantage of an adequate assertive approach and constructive communication, he can obtain approval of parents for example for word evaluation, for using elements of the alternative teaching and so on.

- Negotiation competency - it is closely associated with the assertive competencies, its substance lies in achievement and preservation of students' activity and creativity, and also in ability "to treat" them.

- Interaction competencies - are associated with the principles of humanistic pedagogy; to this belongs congruency (sincerity, openness, acceptance (positive acceptance of a human being), empathy and self-evaluation (creation of conditions for development of a healthy self-consciousness).

- Diagnostic competency - it concerns a complex procedure, the object of which is cognition, assessment and evaluation of the education process and its participants (diagnostic of an individual, diagnostic of a class, diagnostic of the teacher's work, diagnostic of the external conditions, diagnostic of pupils with specific learning disorders and other things).

- Cooperative competency - it is connected with activation teaching methods and modern organizational forms, it $\mathrm{s}$ focused on developing of social relations and cooperation.

- Interpretation competency - teacher interprets to students the reality that is constantly changing, the teacher should be able "to monitor" action in the world, in the nature and in the society and based on this ability to update not only the contents of the curriculum but also the teaching methods, and to complete the educational goals.

- Professional - pedagogical competency - in preparation for the profession the teacher already acquires a number of knowledge not only from his profession, as the teacher's work, beside his pedagogical, psychological and methodical knowledge, requires to use also many other ones; in practice

of the new time], Eds. J. Semrád, A. Vališová, P. Andres, M. Škrabal, Brno 2016; V. Holeček, Psychologie v učitelské praxi [Psychology in the teacher's practice], Praha 2014. 
we can meet with undervalued sociological aspects of teaching (few opportunities for cooperation of students), but also with psychological aspects (as is undervaluation of motivation, underestimation of individual approach to students, disrespecting of teaching styles and other things).

- Realization competencies -these concern an effective preparation of the teachers for the teaching process, which beside other things includes also choice of suitable teaching methods, exercise of didactical principles, choice of organizational forms, formulations of a goal and manners of pupil's performance evaluation.

- Protective competency - it concerns a solicitousness competency, creation of a positive climate in the social group, freeing the students of worries even by means of psycho-hygiene.

- Facilitating competency - teacher as a facilitator is concentrated on all positive things and thus he can develop it and at the same time on the contrary eliminate problems right at the source.

- Moral competency - it concerns teacher's moral self-reflection, meditation over his personality (What kind of a man am I? What kind of a man should I be? Am I a positive example for students?)

- Self-creative competency - in substance it can be said that creativity of students is a "mirror" of the teacher's creativity.

- Cognition competency - a prerequisite of the teacher's activity is his interest about new knowledge, permanent self-education, with emphasis on self-reflection.

- Organizational competency - within it falls the ability to react flexibly on new changing conditions and on various situations arising in the course of teaching, beside preparation for the teaching process.

- Intervention competency - the teacher masters intervention means for securing discipline, and is also able to identify social pathological displays of pupils.

- Didactical - methodical competencies - these competencies represent a direct instrument of management and regulation of the educational process; the teacher analyses the contents of the curriculum in order to be able to update and complement it; it is suitable to use activating and creative methods of teaching for its interpretation and presentation.

- Informational - medial competency - to these competencies is lately paid an increased attention, the teacher should be able to use various information technologies and lead the students to its right using for their personal development; he is able to use a methodical repertoire and adjust it to the individual needs of pupils.

- Creative - authorial competency - the teacher should be creative not only in relation to the teaching process and to the students themselves but 
also to himself; every teacher became in substance an author of the progressive approach to teaching by completion of the curriculum contents.

A number of authors indicate various approaches and different viewpoints to the problems of teacher's competencies. It can cause an impression of some kind of a "views labyrinth" - however, it is substantial that all the mentioned competencies lead to improvement of teacher's activities. Teacher's competencies in its complex form a socalled teacher's professional standard.

\section{Professional standard in the context of key competencies of the higher-education teacher}

Formulation of the professional standard is derived from the exact determination and definition of the individual groups of competencies. It is possible and purposeful to formulate the standards by active verbs in the formulation, i.e. what the educator has learned, of what he is capable, what he can do, what he knows, what he masters and what knowledge he has. Competency of a higher-education teacher can be divided according to the character of his activity into seven spheres. It can of course come about some overlapping but this is quite common and natural at every division and categorization that cannot be quantified or precisely defined. Among the priority competencies of the higher-education teacher can be in particular included the following ones: branch subject competency; pedagogical and psycho-didactical competency; diagnostic and intervention competency; psychosocial and communicative competency; professional and personality cultivating and managerial and normative competency. Further is mentioned a brief characteristic of teacher's individual competencies, in the context of his acquired qualifications, necessary for his higher-education teaching: ${ }^{7}$

- Branch subject competency - in framework of his teaching qualification the teacher is able to transform his knowledge of respective branches into the educational contents; he can integrate the interdisciplinary knowledge and create interdisciplinary relations; he compares professional information from the historical and international point of view; he is able to use his information ability in acquirement and evaluation of professional information; he is methodologically qualified for realization of good quality researches and so on.

- Pedagogical and psycho-didactical competency - the teacher masters educational and learning strategies; he is acquainted with the substance of alternative didactical models; he respects the individuality of students; he effectively takes advantage of informational and communicational technologies

${ }^{7}$ In more detail: M. Slavík a kol., Vysokoškolská pedagogika [Academical pedagogy], Praha 2012, p. 76-80. 
for support of students' learning; he masters specifics of students“ evaluation at higher-education schools; he is informed about the human rights and its respecting in his own pedagogical practise etc.

- Diagnostic and intervention competency - the teacher uses means of pedagogical diagnostic in higher-educational teaching; he is able to identify the specific education needs of students at a higher-education school, masters manners of work with talented students; effectively solves demanding situations and education problems, etc.

- Psychosocial and communicative competency - the teacher masters means of development of a positive school climate in the study group; he is able to find his way in demanding social situations and solve it; he is able to cope with the pedagogical communication and partial communicative strategies and other things.

- Professional and personality cultivating competency - the teacher is psychically and physically capable; he is resilient towards mental strain; he is morally irreproachable; he is able to use his general knowledge at higher-education teaching process, i.e. in the philosophical, cultural, political, legal, and economic sphere; he presents himself as a social and professional example; he masters cooperative skills for work in a team; he masters the self-reflection and self-evaluation; he respects significant aspects of the professional ethic and so on.

- Managerial and normative competency - the teacher is well acquainted with the conditions and processes of higher-education school functioning as a public-law institution; he masters administrative activities connected with students' files and their study results; he becomes a part of outside teaching activities of students and colleagues; he masters projecting and management of grant projects with international participation; he leads the students constructively and creates conditions for effective cooperation in the study group and other things.

\section{Importance of higher-education teacher's digital competencies}

For a long time is already hold a debate about the fact that digital competencies are important and indispensable for teachers at the present-day school $^{8}$ and also for 4.0 education in the 4.0 industry. New trends and needs of the society, the competitiveness of which requires preparedness of the po-

8 For example: P. Svoboda, Assumptions and reasons for use of digital technologies in education, Studia Pedagogiczne, 2017, 50(1); O. Neumajer, Být digitálně gramotný už neznamená jen ovládat počítač [To be digitally literate means no more to work only with the computer], Řizení školy, 2017, 14,3 . 
pulation for demands of the 4.0 industry (National initiative 4.0 Industry), MPO (Ministry of Industry and Commerce). In accordance with the Strategy of digital education up to 2020 each individual, without disparity, should be provided with such competencies that will enable him to assert himself in the information society and take advantage of an open education offer in the course of his whole life. This fact is also in accordance with the Strategy of the educational policy of the Czech Republic (Czech government resolution, 927/5014) the part of which is an appeal to open education to new methods and learning manners by means of digital technologies and to secure conditions for development of digital literacy and informational thinking.

In the centre of research attention are in particular pupils (see for example the analysis of the international research results ICILS 2013 and PISA 2012 focused on using ICT in teaching process and another students' activities). The findings of research in the sphere of social and also technical sciences, after commencement of the $4^{\text {th }}$ industrial revolution, draw attention to a profound transformation of educational processes in the society, the competitiveness of which is based on manners, speed and quality of the processed information. At the same time can be expected a deep transformation of school's educational function that will widely use the personalized learning pathway, independent learning and peer-to-peer activities. To the forefront now come new skills often denoted as skills for the $21^{\text {st }}$ century. This fact can be inferred from the report Innovating Pedagogy 2015 - 2017 and also from the research organization Gartner.com. For example ${ }^{9}$ mentions that we live in a mobile time. Computers, tablets, smartphones and Internet nowadays form an integral part of the everyday life. There is no doubt about the fact that using digital technologies significantly influences social interaction.

Making use of digital technologies as didactical means, focused on teaching goals with a number of motivation elements that are applied into the teaching process on a worldwide scale. Nowadays there exist many questions that concern the influence and impact of digital technologies on education and ask whether its use in the process of teaching is aimed at the goals of teaching. Particularly important is to compare the views of teachers and students. To the digital technologies belong computers, tablets, mobile telephones and Internet, enabling a constant exchange of information in application for education. The young generation uses these technologies intensively. It is possible to enumerate the positive and negative aspects of new technologies and to overcome its discrepancies by taking into account the positive and negative impacts on the young generation. Particularly important is to point out the importance of the mutual learning when making use of Internet.

${ }^{9}$ Gartner.com. 2015, Leading in a Digital World [online], [cit. 2015-12-06]. Available at WWW: http:/ / www.gartner.com. 
Digital technologies are a bearer of changes (innovations) in favour of the teaching hour. These technologies constitute an effective and perspective support of education and are also a positive supporting means of teaching. Digital technologies are also used as a support for improvement of education effectiveness and as an extended manner of teaching for students. It can be stated that the educational process is flexible, within easy reach and individual which corresponds to the needs of quality improvement of education. It is generally hold that without inclusion of the innovative didactical means into teaching the school can lose its credit of a modern educational institution. The modern life brings new technologies denoted as e-technologies (digital technologies). Digital technologies are meaningful for application into the educational reality and help in education of the talented and handicapped students. It is impossible to prepare the students for further education and afterwards for finding employment in the knowledge society and industry 4.0 without digital technologies. This statement is based on the analysis of the presentday situation in teaching of technical subjects at Czech secondary schools and research in this sphere (grant project TAČR - Technological Agency of the Czech Republic "Development of Digital Competencies of Social Sciences Teachers at Secondary Technical Schools")

The European Parliament and Council in 2006 mentioned digital competencies as positive and critical technologies used in the information society (TIS) at work, leisure time and communication. This presumption was based on the basic skills of ICT: Using computers for acquirement, evaluation, storing, for creation and exchange of information, and for communication and cooperation in the framework of nets via Internet. It is necessary to keep in mind that as a cross competency the digital competencies help us to deepen some other competencies as are communication, language skills or skills in the natural sciences. ${ }^{10}$ The document titled "Strategy of digital education up to 2020 speaks about the fact that digital technologies became an integral part of the everyday life of a great part of the advanced world population. Availability of information has changed its development and thus also the manners how to view information and how to work with it. The young generation grows up in the environment in which information and digital technologies are omnipresent. This generation considers work with new technologies as a quite natural part of life, namely for example:

- In taking part in actions at one's surroundings and in the education reality by means of online activities;

${ }^{10}$ R. Vuorikari, Získat digitální kompetence - úkol pro občana 21. století [To acquire digital competencies - a task for the citizen of the 21st century], 2015, [online], [cit. 2015-14-06], Available at WWW: https://www.schooleducationgateway.eu/cz/pub/viewpoints/experts/riina_vuorikari_-_becoming_dig.htm. 
- In using digital technologies for learning and personal development.

The structure of the UNO organization for education, science and culture (UNESCO) of 2011 was simplified by the National Institute for Further Education. It includes in total 6 spheres of teacher's work:

- Strategy;

- Contents of education and teaching environment;

- Pedagogy;

- Digital technologies;

- Organization and administration;

- Further education.

From online instruments for ascertainment of teacher's digital competencies can be selected an instrument that has arisen in the project METEP 2015 - 2018. The competencies are associated into four spheres:

- Digital pedagogy;

- Using and creation of digital sources;

- Communication and cooperation by means of digital technologies;

- Digital citizenship.

Based on the above mentioned facts and professional literature, digital competencies can be currently defined as a complex of knowledge, skills and stances, including the respective qualifications, strategies and values, necessary for using information and communication technologies (ICT) and digital media for fulfilment of tasks, solution of problems, communications, administration of information, collaboration, creation and contents sharing, and also acquirement of knowledge effectively, suitably, critically, and in a creative manner, autonomous, flexibly, ethically and reflectively in relation to work, leisure time, participation, learning, socialization, consumption and strengthening of the position. ${ }^{11}$

According to the European Commission Joint Research Centre DigCompEdu, 2013, 2016 to the most important digital competencies belong:

- Work with information - significance is gaining retrieval of digital contents and its processing. Under this work comes also evaluation of information, critical assessment, analyzing, organizing and storing.

- Communication and cooperation - digital media are means of communication. Communication and cooperation requires purposeful interaction and ability of sharing by means of digital technologies that at the same time enable to take part in civil activities. For these activities, realized in the digital environment, is necessarily to know and respect the information ethics,

11 A. Ferrari, Digital Competence in Practice: An Analysis of Frameworks, Luxembourg 2013, European Commission, [online]. [cit. 2013-10-03]. Available at WWW: http://ftp.jrc.es/EURdoc/JRC68116.pdf. 
netiquette and be able to take care of one's digital identities and also to acquire, administrate and share data, information and contents by using the digital technologies.

- Creation of digital contents - important is creation of a new but also of an existing adapted or remixed digital contents. It is necessary to be well informed about the copyright and licences. For solution of some issues or fulfilment of certain tasks it is also necessary to direct one's attention to the basics of algorithm development and programming. To further abilities belongs the knowledge how to create the contents in various formats and make use of various digital technologies and also to know how to adjust and improve the contents that was already created and create a new one.

- Security - the security contains more partial spheres, from protection of computer systems over protection of personal data and privacy up to health protection, preservation the quality of life and protection of environment.

- Solution of problems - solution of technical problems arising at work with digital devices, equally as selection and use of adequate digital instruments and suitable technological solutions. Creative use of technologies, innovation of traditional procedures and cooperation with the others in this sphere is regarded as more and more important. It is also important to improve one's digital competencies in view of the dynamically developing digital technologies in connection with the industry 4.0.

Digital competency is a basic skill of the $21^{\text {st }}$ century for teachers and students. From the research (NCES - National Center for Education Statistics, 2013) it is evident that the level of digital competency of $40 \%$ of EU population is insufficient and $22 \%$ of citizens do not use Internet at all.

\section{Conclusion}

Effective education is in a number of spheres based on a good quality preparation of the pedagogical personnel. With this fact is associated not only the need of pedagogy development as of a science but also broadening and quality improvement of its teaching at all types and degrees of schools, in particular at higher-education schools and universities. Constitution of an "information society" and "knowledge society" requires - in the humane, technical and social sphere - a higher intervention of pedagogical knowledge and activities, as well as a more dynamic development of the pedagogy itself. Digital competencies can be deepened in connection with the online manners of professional development - for example with massive open online courses MOOC, webinars, blended learning or professional online communities. 


\section{BIBLIOGRAPHY}

Cejpek J., K prirozené autoritě vysokoškolského učitele [To the natural authority of the higher-education teacher], [in:] Relativizace autority a její dopady na současnou mládež [Relativization of authority and its impact on the present-day youth], Ed. A. Vališová a kol., ISV, Praha 2005.

Holeček V., Psychologie v učitelské praxi [Psychology in the teacher's practice], Grada Publishing, Praha 2014.

Jank W., Meyer H., Didaktische Modele, Cornelsen Verlag scriptor, Frankfurt am Main 1991.

Kolář Z. a kol., Výkladový slovník z pedagogiky [Monolingual dictionary from pedagogy], Grada Publishing, Praha 2012.

Kolář Z., Vališová A., Analýza vyučování [Teaching analysis], Grada Publishing, Praha 2009.

Kyriacou Ch., Klíčové dovednosti učitele [Teacher’s key skills], Portál, Praha 1996.

Maňák J., Švec J., Janík T., O vzdělávání, učitelství a tak trochu i o pedagogice [About education, teaching profession and a little about pedagogy], 1. vyd., Masarykova univerzita, Brno 2017.

Neumajer O., Být digitálně gramotný už neznamená jen ovládat počítač [To be digitally literate means no more to work only with the computer], Řízení školy, 2017, 14, 3.

Procházka M., Vítečková M., Pohled lektorů firemního vzdělávání na faktory úspěchu své vzdělávací činnosti [View of the corporate training lectors on factors of their successful education activity], Lifelong Learning - celoživotní vzdělávání, 2016, 6(2).

Prúcha J., Walterová E., Mareš J., Pedagogický slovník. 2. rozšír. a přeprac [Pedagogical dictionary, $2^{\text {nd }}$ extended and reworked edition], Portál, Praha 2009.

Semrád J., Vališová A., Andres P., Škrabal M., Výchova, vzdělávání a výzvy nové doby [Education and challenges of the new time], Paido, Brno 2016.

Slavík M. a kol., Vysokoškolská pedagogika [Academical pedagogy], Grada Publishing, Praha 2012.

Sliwerski B., Pozycja nauczyciela w szkole a jego autorytet, LU, Lodž 2003.

Somr M. a kol., Pedagogika pedagogů [Pedagogy of the educationalists], Tradice a současnost učitelstoí [Tradition and present-day teaching profession], Jihočeská univerzita v Českých Budějovicích, České Budějovice 2012.

Svoboda P., Assumptions and reasons for use of digital technologies in education, Studia Pedagogiczne, 2017, 50(1).

Šafránková M., Franěk R., Některé aktuální problémy vzdělání, vzdělávání a výchovy v současné společnosti a v českém vysokém učení technickém v Praze [Some current problems of education in the contemporary society and in the Czech technical college in Prague], [in:] Výchova, vzdělávání a výzzy nové doby [Education and challenges of the new time], Eds. J. Semrád, A. Vališová, P. Andres, M. Škrabal, Paido, Brno 2016.

Švamberk Šauerová M., Techniky osobnostního rozvoje a duševní hygieny učitele [Technology of personal development and teacher's mental hygiene], Grada Publishing, Praha 2018.

Švec V., Klíčové dovednosti ve vyučování a výcviku [Key skills in teaching process and training], Masarykova univerzita, Brno 1998.

Tomková A., Portfolio v perspective reflektivně pojatého vzdělávání učiteli̊ [Portfolio in the perspective of reflectively approached teacher's education], Pedagogická fakulta UK, Praha 2018.

Tureckiová M., Klíčové kompetence manažerů vzdělávání [Key competencies of education managers], [in:] Pokroky v hodnocení klíčových kompetencí [Progress in evaluation of key 
competencies], Eds. J. Malach, I. Červenková, M. Chmura, Ostravská univerzita, Ostrava 2016.

Vališová A., Jak získávat, udržet a neztrácet autoritu [How to acquire, preserve and not to lose authority], Grada Publishing, Praha 2008.

Vališová A., Kasíková H., Pedagogika pro učitele [Pedagogy for teachers], Grada Publishing (5. dotisk), Praha 2015.

Vašutová J. a kol. Vzděláváme budoucí učitele [We educate future teachers], Portál, Praha 2008.

Veteška J., Tureckiová M., Kompetence ve vzdělávání [Competencies in education], Grada Publishing, Praha 2008.

Wróbel A., Wychowanie a manipulacja, Oficyna Wydawnicza Impuls, Kraków 2011.

Gartner.com. 2015, Leading in a Digital World [online], [cit. 2015-12-06]. Available at WWW: http:/ / www.gartner.com

Innovating Pedagogy 2016, Open Univerzity inovation report [online], [cit. 2016-12-06]. Available at WWW: http://www.open.ac.uk/blogs/innovating/.

Vuorikari R., Ziskat digitální kompetence - úkol pro občana 21. století [To acquire digital competencies - a task for the citizen of the 21 $1^{\text {st }}$ century], 2015, [online], [cit. 2015-14-06], Available at WWW: https:/ / www.schooleducationgateway.eu/cz/pub/viewpoints/ experts/riina_vuorikari_-_becoming_dig.htm

Ferrari A., Digital Competence in Practice: An Analysis of Frameworks, Luxembourg 2013, European Commission, [online]. [cit. 2013-10-03]. Available at WWW: http://ftp.jrc.es/ EURdoc/JRC68116.pdf.

DIGCOMP, A Framework for Developing and Understanding Digital Competence in Europe, Luxembourg 2013: Publications Office of the European Union, [online], [cit. 2013-1003]. Available at WWW: https:/ / ec.europa.eu/jrc/en/digcomp

National Center for Education Statistics 2013, Professional Development: Teachers' need for professional development [online]. [cit. 2013-12-12]. Available at WWW: https:/ / nces.ed.gov/surveys/talis/talis2013/talis2013results_3b.asp

UNESCO 2011, ICT Competency Framework for Teachers. UNESCO and Microsoft: Paříž. [online]. [cit. 2013-12-11]. Available at http://www.unesco.org/new/en/unesco/ themes/icts/teacher-education/ unesco-ict-competency-framework-for-teachers/

School Educational Gateway 2015, Digitální kompetence: zásadní dovednost 21. století pro učitele a studenty [Digital competencies: a principal skill of the $21^{\text {st }}$ century for teachers and students], [online]. [cit. 2018-9-09]. Available at WWW: https://www.schooleducationgateway.eu/cz/pub/resources/tutorials/digital-competence-the-vital-htm

ICILS 2013, Mezinárodní výzkum počítačové a informační gramotnosti [International research of computer a information literacy], [online] [cit. 2018-2-5]. Dostupný (available at) z WWW: <wWw.icils.cz>. 